$\underline{\text { www.cjes.eu }}$

\title{
The problem of evaluating primary school students in the online education process
}

Raissa Izmagambetova ${ }^{{ }_{1}}$, Kazakh National Women's Teacher Training University, Master of pedagogical science, Zerdeli microdistrict, house 182, apartment 59, Almaty sity, Kazakhstan https://orcid.org/0000-0002-8016-7526

Nabuova Roza 2, Kazakh National Women's Teacher Training University, Candidate of pedagogical science, Mamur 7, Almaty, Kazakhstan https://orcid.org/0000-0002-6887-4850

Medeubayeva Kenzhekhan ${ }^{3}$, Kazakh National Women's Teacher Training University Candidate of Pedagogical Science, Almaty, Kazakhstan, Zerdeli microdistrict, house 40, apartment 26, Almaty city, Kazakhstan https://orcid.org/0000-0002-8399-384X

Bainazarova Tursynay ${ }^{4}$, Kazakh National Women's Teacher Training University Candidate of pedagogical science, Almaty, Kazakhstan, Adress:3, Ainabulak microdistrict, Almaty city, Kazakhstan https://orcid.org/0000-0001-7250-6113

Karsybayeva Raissa ${ }^{5}$, Kazakh National Women's Teacher Training University Candidate of pedagogical science, Almaty, Kazakhstan, Adress:101/1, Dosmukhamedov street, Almaty city, Kazakhstan https://orcid.org/0000-0003-3723-089X

\section{Suggested Citation:}

Izmagambetova, R., Roza, N., Kenzhekhan, M., Tursynay, B., \& Raissa, K., (2022). The problem of evaluating primary school students in the online education process. Cypriot Journal of Educational Science.17(1), 255-267. https://doi.org/10.18844/cjes.v17i1.6704

Received from October 20, 2021; revised from November 11, 2021; accepted from January 20, 2022. (C)2022 Birlesik Dunya Yenilik Arastirma ve Yayincilik Merkezi. All rights reserved.

\begin{abstract}
Distant education studies carried out during the COVID-19 pandemic period are handled at different education levels and from different perspectives. The purpose of this research is to evaluate the problem of evaluation of primary school students in online education with the opinions of teachers. This research was carried out by using qualitative research methods. The study group of the research consisted of 25 classroom teachers working in various primary schools in Almaty, Kazakhstan, in the 2021-2022 academic year. A semi-structured interview form was used as a data collection tool in the research. As a result of the research, teachers stated that face-to-face education is more advantageous than distance education in the evaluation of students. The teachers categorized the problems they encountered in the field of measurement and evaluation during the distance education process as technical problems, communication problems, method problems, and student problems. They suggested technical support, communication support, choosing the appropriate method, and motivating the students as the solution to the problems.
\end{abstract}

Keywords: Distance education; evaluation; online education; teacher opinions.

\footnotetext{
* Address of correspondence: Raissa Izmagambetova, Kazakh National Women's Teacher Training University, Master of pedagogical science, Zerdeli microdistrict, house 182, apartment 59, Almaty sity, Kazakhstan Email address: izmagambetova1988@mail.ru
} 
Izmagambetova, R., Roza, N., Kenzhekhan, M., Tursynay, B., \& Raissa, K., (2022). The problem of evaluating primary school students in the online education process. Cypriot Journal of Educational Science.17(1), 255-267. https://doi.org/10.18844/cjes.v17i1.6704

\section{Introduction}

It is a fact that Covid-19 has significantly affected our lives. As in every field, it has caused significant changes in the field of education from beginning to end. Since the first appearance of the disease in December 2019 (Wu \& McGoogan, 2020), it has affected the whole world dramatically. The Covid-19 epidemic continues to negatively affect all aspects of life in the world. In this context, it is the first time that such a large global scale has been affected in education. In this process, educational institutions at all levels, from pre-school to higher education, were quickly closed to limit the spread of the new Coronavirus disease (COVID-19) in many countries of the world. For approximately 1.58 billion students ( $91.4 \%$ of enrolled students), learning activities have stopped and almost all education systems have started to use distance education solutions (ILO, 2020).

\subsection{Theoretical and conceptual framework}

As a quick solution to the crisis caused by the COVID-19 epidemic, educational institutions structured according to face-to-face education started to work immediately and switched to distance education to continue the courses and programs with web-based distance education instead of faceto-face education (Gewin, 2020). According to Moore and Kearsley (2005), distance education is an institutionally planned administrative arrangement where teachers and students are in different places, and which requires the use of certain technologies together with the teaching methods applied depending on the specially prepared course design. According to Holmberg (1995), distance education is a form of education in which the teacher and the student are not sided by side and carried out with various communication tools. Distance education is a form of education in which students, teachers, and teaching materials from different geographies are brought together through communication technologies (Al \& Madran, 2004).

We can list some of the main features that distinguish distance education from the traditional formal education system as learning objectives, methods, content, measurement and evaluation processes, the place of distance education, when it is applied, and the fact that distance education does not have a long history compared to traditional education (Eygu \& Karaman, 2013). . Distance education, which is compulsory during the pandemic period, has changed the lives of all stakeholders, especially teachers, students, and parents. Academicians, teachers, students, and parents related to education tried to adapt to the "education system of the changing world" that they had not experienced before. This mandatory process brought along different difficulties (Zan \& Zan, 2020).

Technology-supported learning environments have also revealed quite a different course design and requirements from traditional teaching (Valenta et al., 2001). Primary school students are among the groups that have the most difficulty in distance education due to the limitations in their cognitive, affective, and psychomotor characteristics (Szente, 2020). Since there is no direct interaction in this type of education, it can be said that especially primary school students are negatively affected. Because primary school students in the concrete operational period need to be supported emotionally and visually by using materials by communicating with their teachers (Fidan, 2008). One of the most important parts that will increase the continuity of the distance education process and the communication with the students is the feedback we will give them.

It is thought that measurement and evaluation are especially important to determine the success rate of the aims of the training and how much individuals receive from the presentation and to provide feedback to the theory (Iskenderoglu et al, 2012). For the teaching process to be carried out completely, and for the curriculum to be implemented correctly, the learning experiences should be carried out together with appropriate measurement-evaluation activities. Similarly, in curricula, 
Izmagambetova, R., Roza, N., Kenzhekhan, M., Tursynay, B., \& Raissa, K., (2022). The problem of evaluating primary school students in the online education process. Cypriot Journal of Educational Science.17(1), 255-267. https://doi.org/10.18844/cjes.v17i1.6704

"assessment and evaluation studies should be in harmony with all components of the curriculum, and the limits of learning outcomes and explanations should be taken as a basis (Koc, 2021).

\subsection{Related research}

Some studies in the field; showed that long-term school closures, quarantine periods, and house arrest can have negative effects on students' physical, mental, spiritual, and psychological health (Brazendale et al., 2017). Evaluating the obstacles to distance education (Gregory \& Lodge, 2015), examining student psychology during the quarantine period (Stewart, Watson \& Campbell, 2018), and examining the effects of distance education on the attitudes, social relations, and communication skills of students in different education levels (Poellhuber, Anderson \& Roy, 2011) studies have been carried out.

Yurtbakan and Akyıldız (2020) evaluated the views of primary school students, their parents, and classroom teachers on distance education activities in their study. As a result of the research, they determined that the students learn better because they can interact with their teachers at school and get feedback, and therefore they prefer face-to-face education at school. Hilli (2020), in his study with teachers in a primary school in a rural area, found that teachers are not sure whether students understand in distance lessons, they are afraid of losing classroom control, they have difficulties in planning due to cultural differences, and they spend serious effort and time in preparing materials and planning.

Andrisyah \& Ismiatun (2021) examined the self-efficacy skills of teachers in early childhood distance education practices in this study. In the research, it was concluded that the covid-19 epidemic affected early childhood education and that educators had a hard time educating children. Considering that situations such as teacher-student, student-student, and eye contact occur in an extremely limited way in the distance education process, Riva et al. (2021), considering that primary school students need social interaction very much, it is necessary to make important arrangements to eliminate this limitation indicated that it should be done.

It is seen that distance education studies carried out during the pandemic process are handled at different education levels and from different perspectives. It is seen that the most important role in the success of the students, who are generally in the focus of the studies, in the distance education process falls on the teachers. Accordingly, in this study, teachers' views on the evaluation of primary school students, who are thought to be one of the important problems of the distance education process, in the online education process were evaluated.

\subsection{Purpose of the research}

The aim of this study is to evaluate the problem of evaluation of primary school students in online education with the opinions of teachers. In this direction, the following sub-objectives were established in the research.

1. What are primary school teachers' preferences for face-to-face and distance education in the evaluation of students?

2. What are the primary school teachers' views on the effectiveness of evaluating students in distance education?

3. What kind of problems did primary school teachers encounter in the field of measurement and evaluation in the distance education process?

4. What are the solution suggestions for the problems experienced in the field of measurement and evaluation in the distance education process of primary school teachers? 


\section{Method and Materials}

In this part of the research, information about the method used in the research, the study group of the research, data collection tools, data collection process, and data analysis are given.

\subsection{Research method}

This research was carried out by using the qualitative research method. Qualitative research is one of the forms of knowledge production developed by people to understand their potential, to solve their secrets, and to explore the depths of the social structures and systems they have built with their efforts. In studies designed with the qualitative method, there is an effort to reach a deep perception about the event or phenomenon examined (Morgan, 1996). In this study, teachers' views on the problem of evaluating primary school students in online education were discussed.

\subsection{Participants}

Since the statistical analysis was not aimed at the participatory study of the research, the purposive sampling method was adopted in determining the study group. The most appropriate approach, which explains the problem in the study in detail, is to prepare environments that will facilitate in-depth research with a small group (Ritchie et al., 2003). In purposive sampling practices, criterion sampling and outlier sampling approaches, which are thought to better explain the research problem, were preferred. With criterion sampling, the basic features of the subject to be researched and the basic criteria that the researcher considers important were created. It is the creation of a different working group that is thought to contribute to the detailed explanation of the problem situation with outlier sampling (Ritchie et al., 2003). In this context, while choosing the teachers to be included in the study, the criterion was determined as having carried out distance education applications during the epidemic period. In addition, following the contrary situation pattern, it was determined that the teachers both gave face-to-face training before the epidemic and gave distance education during the epidemic period. The study group of the research consists of classroom teachers working in various primary schools in Almaty, Kazakhstan, in the 2021-2022 academic year. The teachers in the study group were chosen voluntarily. Information on the demographic characteristics of primary school teachers who voluntarily agreed to participate in the study is given in Table 1.

Table 1: Demographic characteristics of primary school teachers

\begin{tabular}{lcc}
\hline Gender & F & \% \\
\hline Female & 11 & 44 \\
Male & 14 & 56 \\
Sum & 25 & 100 \\
Professional experience & $\mathrm{F}$ & $\%$ \\
3-6 Years & 2 & 8 \\
7-10 Years & 3 & 12 \\
11-14 Years & 13 & 52 \\
15 Years and above & 7 & 28 \\
Sum & 25 & 100 \\
Class of Education & $\mathrm{F}$ & $\%$ \\
1. Class & - & - \\
2.Class & 9 & 36 \\
3.Class & 6 & 24 \\
4.Class & 10 & 40 \\
Sum & 25 & 100 \\
\hline
\end{tabular}


In Table 1, demographic information about the gender, professional experience, and class distribution of the primary school teachers participating in the research is given. Eleven (11) of the teachers participating in the research are female and 14 are male. 2 of the teachers participating in the research have 3-6 years, 3 have 7-10 years, 13 have 11-14 years and 7 have 15 years or more professional experience. While no teacher was teaching the 1st grades among the teachers participating in the research, 9 teachers teaching the 2 nd grade, 6 teaching the 3rd grade, and 10 teaching the 4 th grade participated in the research.

\subsection{Data collection tools}

A semi-structured interview form was used as a data collection tool in the research. In a semistructured interview, the interview form includes a list of questions or topics to be covered. In the interview method, the interview form is prepared to receive the same type of data from different people on similar topics (Patton, 1987). In semi-structured interviews, the questions prepared before are asked to the participants in the same way and the same order, and additional questions are provided where necessary, providing the details of the views. Care was taken to ensure that the interview questions were appropriate for the research and the answers of the participants based on their field of expertise. Before the interviews were held with the main participants, to determine the validity of the interview questions, it was presented to two faculty members who had researched in the field of distance education to get an expert opinion and necessary corrections were made. Afterward, a pilot interview was conducted with a lecturer who teaches in the classroom teaching department, and the question patterns were simplified, it was determined which probes should be used in which question, and the order of the questions was changed. As a result of the corrections made, the interview form has a structure consisting of 4 main questions. The semi-structured interview form is given below.

Table 2: Semi-structured interview form for teachers

Demographic Information:

Teacher's Gender:

Teacher's Professional Experience:

Class of Teacher Training:

Research Questions:

1. Which one do you prefer face-to-face education and distance education in the evaluation of students?

2. What are your views on the effectiveness of evaluating students in distance education?

3. What kind of problems do you encounter in the field of measurement and evaluation in the distance education process?

4. What are your suggestions for solutions to the problems experienced in the field of measurement and evaluation in the distance education process?

\subsection{Data collection process}

The teachers constituting the study group of the research were contacted through their primary schools and informed about the content and ethical principles of the research. Then, the teachers were informed that the semi-structured interview form would be sent to them by e-mail. The semistructured interview form, which was created to collect the research data, was sent to the teachers participating in the research via e-mail, taking into account the measures of the Covid-19 pandemic process. It took approximately 2 weeks for the teachers participating in the study to deliver the semistructured interview forms to the researchers. 


\subsection{Data analysis}

To analyze the data of the research, the content analysis method, which is frequently used in qualitative research, was used. Since content analysis is an inductive type of analysis, it focuses on the origins of the investigated phenomenon or event. Through coding, the concepts underlying the data and the relationships between these concepts are revealed (Merriam \& Grenier, 2019). The answers given by the teachers participating in the research to the questions in the semi-structured interview form were presented in the research by revealing the concepts and the relations between them through coding. The answers given by the teachers participating in the research to the questions in the semi-structured interview form were shared in the research by keeping their identity information confidential.

\section{Results}

This section covers the evaluation of the responses of the study group to the data collection tool.

In Table 3, the answers of primary school teachers regarding face-to-face education and distance education preferences in the evaluation of students are given.

Table 3: Opinions of teachers regarding face-to-face education and distance education preferences in the evaluation of students

\begin{tabular}{|c|c|c|c|}
\hline Theme & Teacher Opinions & $\mathbf{F}$ & $\%$ \\
\hline \multirow{7}{*}{ Face to face education } & $\begin{array}{l}\text { - It is much easier to measure student achievements } \\
\text { in face-to-face education. It is possible to do this by } \\
\text { applying exams suitable for the level of the student. }\end{array}$ & \multirow{7}{*}{25} & \multirow{7}{*}{100} \\
\hline & $\begin{array}{l}\text { - Assessment and evaluation practices can be done in } \\
\text { a much healthier way in the classroom environment. }\end{array}$ & & \\
\hline & $\begin{array}{l}\text { - It is exceedingly difficult to evaluate students in } \\
\text { distance education, especially at the primary school } \\
\text { level. That is why I find face-to-face training } \\
\text { advantageous. }\end{array}$ & & \\
\hline & $\begin{array}{l}\text { - Distance education is not a suitable platform for the } \\
\text { evaluation of learning activities of primary school } \\
\text { students. }\end{array}$ & & \\
\hline & $\begin{array}{l}\text { - Although I think that distance education is an } \\
\text { effective way to continue education and training } \\
\text { activities, the most effective form of education for the }\end{array}$ & & \\
\hline & $\begin{array}{l}\text { evaluation process of students is face-to-face } \\
\text { education. }\end{array}$ & & \\
\hline & $\begin{array}{l}\text { - I think that the healthiest assessment and } \\
\text { evaluation environment, especially for primary school } \\
\text { students, is face-to-face education. }\end{array}$ & & \\
\hline Distance Learning & - & - & - \\
\hline Sum & & 25 & 100 \\
\hline
\end{tabular}

In Table 3, it is seen that all of the teachers stated that face-to-face education is more advantageous than distance education in the evaluation of students.

In Table 4, primary school teachers' views on the effectiveness of evaluating students in distance education are evaluated. 
Izmagambetova, R., Roza, N., Kenzhekhan, M., Tursynay, B., \& Raissa, K., (2022). The problem of evaluating primary school students in the online education process. Cypriot Journal of Educational Science.17(1), 255-267. https://doi.org/10.18844/cjes.v17i1.6704

Table 4: Opinions of teachers on the effectiveness of evaluating students in distance education

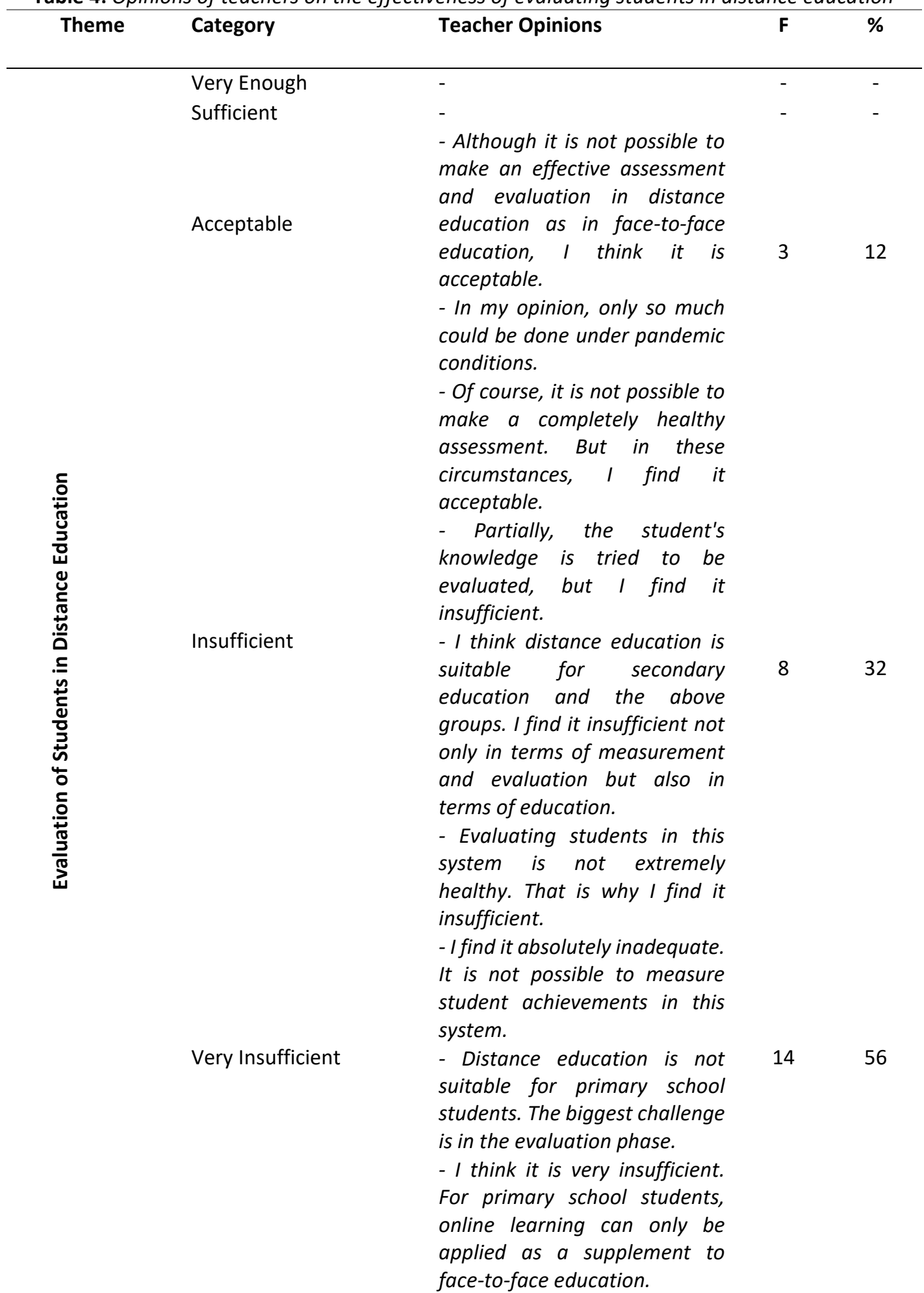

In Table 4, $12 \%$ of the teachers considered the evaluation of students in distance education at an acceptable level. While $32 \%$ of the teachers found the evaluation of students in distance education insufficient, $56 \%$ found it very inadequate. Among the teachers participating in the research, no teacher finds the evaluation of students in distance education very sufficient or sufficient. 
In Table 5, the problems faced by the primary school teachers participating in the research in the field of measurement and evaluation in the distance education process are evaluated.

Table 5: Problems faced by teachers in the field of measurement and evaluation in the distance education

\begin{tabular}{llll}
\multicolumn{3}{l}{ process } & \\
\hline Themes & Teacher Opinions & F & $\%$ \\
\hline & - There may be technical problems caused by internet access at the & \\
student's home. &
\end{tabular}

Technical - It is a huge problem that students are not given education on computer Issues and internet use.

- Distance education can cause technical problems related to computers and the internet not only at the evaluation stage but also at every stage of education.

- Failure to establish healthy communication with the student can be a problem during the evaluation phase.

- When healthy communication cannot be established, neither the training nor the evaluation phase is as efficient as desired.

Communicati - When children cannot communicate with the teacher in the classroom environment, this situation also appears as a problem in the evaluation process.

- It is difficult to decide which method is healthier.

- It is a big problem to apply the methods used in the classroom environment in distance ethics, especially for primary school children.

Method $\quad-$ I do not think that the evaluation method techniques that can be used in distance education are suitable for primary school students.

- Students cannot be motivated during the evaluation process as they are in the classroom environment.

Student Issues - Students are very inadequate in formatting and reporting information in distance education.

- The student does not take the assessment process seriously, as there is no fear of passing the course.

In Table 5, $80 \%$ of the teachers stated that they had technical problems, $64 \%$ had communication problems, $48 \%$ had method problems and $28 \%$ had student problems.

In Table 6, the solution proposals of the primary school teachers participating in the research regarding the problems experienced in the field of measurement and evaluation in the distance education process were evaluated.

Table 6: Solution suggestions of teachers regarding the problems experienced in the field of measurement and evaluation in the distance education process

\begin{tabular}{llc}
\hline Themes & Teacher Opinions & F \\
\hline & - To solve the technical problems experienced, internet access must be & \\
& provided uninterruptedly.
\end{tabular}


Technical

Support

\section{Support}

\section{Appropriate Method Selection}

Motivating the Student
- A 24-hour hotline should be established for technical problems experienced by students and teachers.

- To solve the technical problems experienced by the students, infrastructure support should be provided to eliminate internet interruptions.

- It is necessary to establish healthier communication with students.

- One of the most important problems, I think, is the lack of communication. Communication between the student and the teacher needs to be planned and programmed.

- The communication between children and with the teacher needs to be raised to the communication standards established in the classroom environment.

- It is necessary to determine the most appropriate evaluation method for primary school students in distance education so that the student does not become a victim of the method in the reporting phase of information.

- I do not think that methods such as homework, written and multiplechoice tests are suitable for primary school students in distance education. The right method must be chosen.

- It is necessary to determine the most appropriate method that allows the healthy evaluation of primary school students in terms of measurement and evaluation.

- Students need to be motivated. Provide psychological support when needed

- It is the duty of the parents as well as the teachers to keep the students excited. The motivation of students should be increased by providing teacher-parent cooperation.

- A reward system can be established to increase student interest.

In Table $6,84 \%$ of the teachers stated providing technical support, $68 \%$ communication support, $36 \%$ choosing the appropriate method, and $42 \%$ motivating students as solution suggestions for the problems experienced in the field of measurement and evaluation in distance education process.

\section{Discussions}

When primary school teachers were asked about their preferences for face-to-face education and distance education in the evaluation of students, it was seen that all of the teachers stated that face-to-face education was more advantageous than distance education. Although Talidong \& Toquero (2020) state that the general views on distance education are negative, it is an important finding that it provides opportunities for the continuity of education during the pandemic period. The opinions of the primary school teachers participating in the research on the effectiveness of the 
evaluation of students in distance education are mostly inadequate and very inadequate. In line with the research findings, Sintema (2020) in his study reveals that teachers cannot make effective assessment and evaluation in this process and that more research is needed on how assessment should be done in distance education.

The problems faced by the primary school teachers participating in the research in the field of measurement and evaluation in the distance education process; technical problems, communication problems, method problems, and student problems. Saygi (2020) also stated in her study that one of the problems faced by classroom teachers during the Covid 19 process is the insufficient technological infrastructure. Similarly, in the study conducted by De Paepe et al. (2018), it was stated that one of the negative aspects of distance education is the lack of technical support. Parallel to the problems related to communication in the study, Fidalgo et al. (2020) found that the lack of rapid feedback in distance education caused a limitation in the evaluation. Sercemeli and Kurnaz (2020) also stated in their study on students that one of the disadvantageous aspects of distance education is the lack of interaction between teacher and student. Al-Smadi et al. (2012) stated in their study that students have different learning styles or that teachers evaluate the learning process for different purposes, making it necessary to prefer alternative measurement tools.

The solution suggestions of the teachers participating in the research regarding the problems experienced in the field of measurement and evaluation in the distance education process; technical support, communication support, appropriate method selection, and motivating the student. In their study, Biyikli and Ozgur (2020) focused on teachers' suggestions, making changes in teaching methods and techniques, establishing healthy communication with students, carrying out activities that increase student motivation, solving technology-related problems, completing student deficiencies with quick feedback, parent, school, teacher cooperation and process evaluation categorized as the basis.

\section{Conclusion}

Distance education applications, which have become widespread all over the world with the Covid-19 pandemic process, have many problems in themselves but have become an area of importance, especially considering student readiness at the primary education level. What are the most reliable and objective measurement and evaluation methods in distance education is one of the problems experienced in primary education. Therefore, this study, it is aimed to evaluate the problem of evaluating primary school students in online education with the views of teachers. As a result of the research, teachers stated that face-to-face education is more advantageous than distance education in the evaluation of students.

Teachers' views on the effectiveness of evaluating students in distance education are insufficient and very inadequate. While the teachers categorized the problems they encountered in the field of measurement and evaluation during the distance education process as technical problems, communication problems, method problems, and student problems, they suggested technical support, communication support, choosing the appropriate method, and motivating the students for the solution of the problems.

\section{Recommendations}

In line with the results obtained from the research, it is seen that it is especially important to eliminate the problems related to the evaluation of primary school students in the distance education process. In the distance education process, the technical infrastructure should be created to meet the needs of students. Student-teacher communication should be established healthily. It is necessary to 
apply new methods in the evaluation of students. In addition, it is recommended to organize seminars blended with activities aimed at informing and motivating students about the evaluation process in distance education.

\section{References}

Al, U., \& Madran, O. (2004). Web-based distance education systems: Must-have features and standards. Information World, 5(2), 259-271. https://doi.org/10.15612/BD.2004.491

Al-Smadi, M., Wesiak, G., Guetl, C., \& Holzinger, A. (2012, July). Assessment for/as learning: Integrated automatic assessment in complex learning resources for self-directed learning. In Proceedings of the 2012 Sixth International Conference on Complex, Intelligent, and Software Intensive Systems (CISIS) (pp. 929-934). https://dl.acm.org/doi/abs/10.1109/CISIS.2012.210

Andrisyah, A. And İsmiatun, A. N. (2021). The Impact of Distance Learning Implementation in Early Childhood Education Teacher Profesional Competence. Jurnal Obsesi: Jurnal Pendidikan Anak Usia Dini, 5(2), 1815-1824. https://pdfs.semanticscholar.org/6732/2b2150e43fddfe6b0311989aed5491804762.pdf

Bıyıklı, C. \& Özgür, A.O. (2021). The problems experienced by teachers in the synchronous distance education process during the Covid-19 pandemic period.solution proposals. Journal of Open Education Applications and Research (AUAd), 7(1), 110-147. https://dergipark.org.tr/en/download/article-file/1304972

Brazendale, K., Beets, M. W., Weaver, R. G., Pate, R. R., Turner-McGrievy, G. M., Kaczynski, A. T., ... \& von Hippel, P. T. (2017). Understanding differences between summer vs. school obesogenic behaviors of children: the structured days' hypothesis. International Journal of Behavioral Nutrition and Physical Activity, 14(1), 1-14. https://ijbnpa.biomedcentral.com/articles/10.1186/s12966-017-0555-2

De Paepe, L., Zhu, C., \& DePryck, K. (2018). Drop-out, Retention, Satisfaction, and Attainment of Online Learners of Dutch in Adult Education. International Journal on E-Learning, 17(3), 303-323. https://www.learntechlib.org/primary/p/174173/

Eygu, H., \& Karaman, S. (2013). A research on satisfaction perceptions of distance education students. Kırıkkale University Journal of Social Sciences, 3(1), 36-59. https://dergipark.org.tr/en/pub/kusbd/issue/19375/205547

Fidalgo, P., Thormann, J., Kulyk, O., \& Lencastre, J. A. (2020). Students' perceptions on distance education: A multinational study. International Journal of Educational Technology in Higher Education, 17, 1-18. https://link.springer.com/content/pdf/10.1186/s41239-020-00194-2.pdf

Fidan, N. K. (2008). Teachers' views on the use of equipment in primary education. Journal of Theoretical Educational Science, 1(1). https://www.researchgate.net/profile/NurayKurtdede-

Fidan/publication/285755145 Teachers' views with regard to the use of tools and ma terials in the primary level/links/57e2427608ae9e25307e481a/Teachers-views-withregard-to-the-use-of-tools-and-materials-in-the-primary-level.pdf

Gewin, V. (2020). Five tips for moving to teach online as COVID-19 takes hold. Nature, 580(7802), 295296.

https://moodle.technion.ac.il/pluginfile.php/1647117/mod resource/content/1/CAREER\%2 OFEATURE.pdf 
Gregory, M. S. J., \& Lodge, J. M. (2015). Academic workload: the silent barrier to the implementation of technology-enhanced learning strategies in higher education. Distance education, 36(2), 210-230. https://doi.org/10.1080/01587919.2015.1055056

Hilli, C. (2020). Distance teaching in small rural primary schools: a participatory action research project. Educational Action

Research, 28(1),

38-52.

https://doi.org/10.1080/09650792.2018.1526695

Holmberg, B. (2005). Theory and practice of distance education. Routledge. https://doi.org/10.4324/9780203973820

International Labour Organisation (ILO) Raport (2020) https://www.ilo.org/ankara/areas-ofwork/covid-19/WCMS 742726/lang-- tr/index.htm

Iskenderoglu, M., Iskenderoglu, T. A., \& Palanci, M. (2012). Opinion of teaching staff in distance education systems, regarding the assessment and evaluation process. Procedia-Social and Behavioral Sciences, 46, 4661-4665. https://doi.org/10.1016/j.sbspro.2012.06.314

Koc, E. S. (2021). Investigation of the Suitability of Primary School Curriculum for Distance Education, which became widespread after COVID-19. International Anatolia Academic Online Journal Social Sciences Journal, 7(1), 24-36. https://dergipark.org.tr/en/download/articlefile/1466713

Merriam, S. B., \& Grenier, R. S. (Eds.). (2019). Qualitative Research in Practice: Examples for Discussion and Analysis. John Wiley \& Sons. https://books.google.com.tr/books?hl=tr\&lr=\&id=u9WCDWAAQBAJ\&oi=fnd\&pg=PP2\&ots=q TucFpl3PA\&sig=|xLNpZ4Eud75w0vo1k9iQdOeyS4\&redir esc=y\#v=onepage\&q\&f=false

Moore, M. G., \& Kearsley, G. (2011). Distance education: A systems view of online learning. Cengage Learning. https://books.google.com.tr/books?hl=tr\&lr=\&id=dU8KAAAAQBAJ\&oi=fnd\&pg=PR4\&ots=D3 -cZXBtjy\&sig=-6CggDe244OB8QVBvDBLHNcrAUA\&redir esc=y\#v=onepage\&q\&f=false

Morgan, D. L. (1996). Focus groups as qualitative research (Vol. 16). Sage publications. https://dx.doi.org/10.4135/9781412984287.n2

Saygi, H. (2021). Problems faced by classroom teachers during the Covid-19 pandemic distance education process. Journal of Open Education Practices and Research, 7(2), 109-129. https://dergipark.org.tr/en/pub/auad/issue/62130/841632

Sercemeli, M., \& Kurnaz, E. (2020). A research on students' perspectives on distance education and distance accounting education during the Covid-19 pandemic period. International Journal of Social Sciences Academic Research, 4(1), 40-53 https://dergipark.org.tr/en/pub/utsobilder/issue/55152/741358

Sintema, E. J. (2020). Effect of COVID-19 on the performance of grade 12 students: Implications for STEM education. Eurasia Journal of Mathematics, Science and Technology Education, 16(7), em1851. https://doi.org/10.29333/ejmste/7893

Ritchie, J., Lewis, J., Nicholls, C. M., \& Ormston, R. (Eds.). (2013). Qualitative research practice: A guide for social science students and researchers. sage. https://books.google.com.tr/books?hl=tr\&|r=\&id=EQSIAwAAQBAJ\&oi=fnd\&pg=PP1\&ots=ITOjp t5M\&sig=RwPtpCzwkrogfuJGt4xvU25eiZo\&redir esc=y $\# v=0$ nepage\& $q \& f=f a l s e$

Poellhuber, B., Anderson, T., \& Roy, N. (2011). Distance students' readiness for social media and collaboration. The international review of research in open and distributed learning, 12(6), 102-125. https://doi.org/10.19173/irrodl.v12i6.1018 
Riva, G., Wiederhold, B. K., \& Mantovani, F. (2021). Surviving COVID-19: The Neuroscience of Smart Working and Distance Learning. Cyberpsychology, Behavior, and Social Networking, 24(2), 7985. https://doi.org/10.1089/cyber.2021.0009

Stewart, H., Watson, N., \& Campbell, M. (2018). The cost of school holidays for children from lowincome families. Childhood, 25(4), 516-529. https://doi.org/10.1177\%2F0907568218779130

Szente, J. (2020). Live virtual sessions with toddlers and preschoolers amid COVID-19: Implications for early childhood teacher education. Journal of Technology and Teacher Education, 28(2), 373380. https://www.learntechlib.org/primary/p/216174/

Talidong, K. J. B., \& Toquero, C. M. D. (2020). Philippine teachers' practices to deal with anxiety amid COVID-19. Journal of Loss and Trauma, 25(6-7), 573-579. https://www.tandfonline.com/doi/abs/10.1080/15325024.2020.1759225

Wu, Z., \& McGoogan, J. M. (2020). Characteristics of and important lessons from the coronavirus disease 2019 (COVID-19) outbreak in China: summary of a report of 72314 cases from the Chinese Center for Disease Control and Prevention. Jama, 323(13), 1239-1242. https://jamanetwork.com/journals/jama/article-abstract/2762130

Valenta, A., Therriault, D., Dieter, M., \& Mrtek, R. (2001). Identifying student attitudes and learning styles in distance education. Journal of asynchronous learning networks, 5(2), 111-127. https://pdfs.semanticscholar.org/c8d5/bf92dde0e60d2dfb33e10630b9b0e333e2ae.pdf

Yurtbakan, E., \& Akyildiz, S. (2020). Views of classroom teachers, primary school students, and parents on distance education activities implemented during the Covid-19 isolation period. Electronic Turkish Studies, 15(6). https://web.s.ebscohost.com/ehost/pdfviewer/pdfviewer?vid=0\&sid=3503b48f-8d45-44289237-ec81ee90935f\%40redis

Zan, N., \& Zan, B. U. (2020). Education in an Emergency with Coronavirus: An Overview of Faculty of Letters Students Included in the Distance Education System from Different Regions of Turkey. Electronic Turkish Studies, 15(4). https://websitem.karatekin.edu.tr/user files/nurayzan/yayinlar/20200930 7f1a42436cf845 7cb32e9052de692f28.pdf 